\title{
Hormonal and renal differences between low dose and high dose angiotensin converting enzyme inhibitor treatment in patients with chronic heart failure
}

\author{
Neil C Davidson, Wendy J Coutie, David J Webb, Allan D Struthers
}

\begin{abstract}
Objective-To assess the differential effects of low dose $(5 \mathrm{mg})$ and high dose (20 mg) lisinopril treatment on cardiovascular hormones, renal function, and blood pressure over 24 hours in patients with heart failure.

Design-Double-blind crossover study. Setting-Department of Clinical Pharmacology, Ninewells Hospital and Medical School, Dundee.

Patients-19 patients with chronic heart failure and left ventricular ejection fraction $\leqslant 45 \%$.

Results-Plasma concentrations of aldosterone and endothelin were lower on the $20 \mathrm{mg}$ dose (plasma aldosterone mean at peak drug effect: $90.7 v 152.0 \mathrm{pg} / \mathrm{ml}$, $P<0.001$; mean at trough effect: $124.7 v$ $174.4 \mathrm{pg} / \mathrm{ml}, P<0.01$; plasma endothelin at trough effect $4.70 v 6.04 \mathrm{pmol} / 1, P=$ $0.03)$. Creatinine clearance was lower on $20 \mathrm{mg}$ lisinopril $(68.7 v 82.1 \mathrm{ml} / \mathrm{min}$, $P<0.05)$. The area under the curve for diastolic blood pressure over 24 hours was significantly lower on $20 \mathrm{mg}$ (mean difference $3.0 \mathrm{~mm} \mathrm{Hg}, P=0.04$ ); for systolic blood pressure there was a similar trend (mean difference $5.7 \mathrm{mmHg}, P=0.05$ ). Plasma concentrations of atrial natriuretic peptide (ANP) and B-type natriuretic peptide were similar for both doses; urinary excretion of ANP was lower on $20 \mathrm{mg}(12.2$ v $13.6 \mathrm{pmol}$, $P<0.05$ ).
\end{abstract}

Conclusions-These results indicate that within the usual therapeutic range, high doses of lisinopril cause greater suppression of selected cardiovascular hormones than low doses in heart failure, but are associated with lower creatinine clearance in some patients.

(Heart 1996;75:576-581)

Keywords: heart failure; ACE inhibition; lisinopril; hormones

The role of angiotensin-converting enzyme (ACE) inhibitors in the treatment of heart failure is well-established but the optimal dose is unknown. Each of the large studies that showed improved survival with ACE inhibitors in heart failure used relatively high doses of enalapril: in CONSENSUS the mean dose was $18.4 \mathrm{mg},{ }^{1}$ in VeHFT II it was $15 \mathrm{mg}^{2}$ and in the SOLVD treatment limb it was $16.6 \mathrm{mg}$. $^{3}$ Often the doses of ACE inhibitors prescribed for patients with heart failure in clinical practice are much lower, although there is little evidence to suggest that these low doses are effective. ${ }^{4}$ The effects of low dose $(5 \mathrm{mg}$ once a day) and high dose ( $35 \mathrm{mg}$ once a day) lisinopril on mortality in over 3000 patients with severe heart failure will be determined by the international ATLAS trial which is due to be completed in 1997.

It is evident from heart failure research that the hormonal response to drug treatment is a major determinant of its efficacy. ACE inhibitors have a range of hormonal effects in addition to inhibiting the conversion of angiotensin I to angiotensin II; ACE itself is a non-specific enzyme with several substrates, including bradykinin - a peptide with a range of cardiovascular and renal effects. ACE inhibitors may therefore increase the activity of bradykinin $^{5}$ and may also indirectly affect the turnover of other vasoactive peptides, such as the endothelins that are released from endothelial cells in response to angiotensin II. ${ }^{6}$ The haemodynamic effects of ACE inhibitors may also influence the release of the cardiac natriuretic peptides, atrial natriuretic peptide (ANP) and B-type natriuretic peptide (BNP). ${ }^{7}$ Recent studies have shown that raised plasma concentrations of these peptides are important adverse prognostic indicators in patients with ischaemic heart disease, ${ }^{89}$ suggesting that a reduction in their secretion rates from the heart with treatment may predict a long-term benefit.

Though it is likely that these diverse hormonal effects of ACE inhibitors, and their biological consequences, will have different dose-response relations, there are few data available on the dose-related effects of ACE inhibitors. In this study we compared directly the effects of two doses of an ACE inhibitor, lisinopril, in a crossover trial in patients with heart failure who were already on long-term ACE inhibitor treatment. The doses used (5 $\mathrm{mg}$ once a day and $20 \mathrm{mg}$ once a day) were chosen to represent the bottom end and the top end of the usual therapeutic range in heart failure. Furthermore in this study we measured blood pressure and plasma and urine electrolyte and hormonal concentrations over a 24 hour period to explore possible differences between the doses at both peak and trough drug effect. 


\section{Patients and methods}

We performed a double blind, randomised, crossover study to compare the effects of low dose and high dose lisinopril in patients with heart failure over a 24 hour period. The study protocol was approved by the local committee on medical research ethics. Twenty one patients with symptomatic heart failure secondary to ischaemic heart disease (NYHA class II-III) and left ventricular ejection fraction (LVEF) $\leqslant 45 \%$ were recruited. All patients gave informed consent to participate in the study. Two patients were unable to complete the study protocol for personal reasons and were therefore excluded from the efficacy analyses. All patients had been treated with a diuretic and ACE inhibitor for at least one month before the study. LVEF was measured by radionuclide ventriculography within three months of the study.

During a two week run-in period all patients were treated with lisinopril $10 \mathrm{mg}$ once a day in place of their usual ACE inhibitor medication and in combination with their usual diuretic treatment. After two weeks, patients were randomised to change their dose of lisinopril to either $5 \mathrm{mg}$ once a day or $20 \mathrm{mg}$ once a day in addition to their usual dose of diuretic (fig 1). This new dose lasted for two weeks; on the final day of the two week period on this treatment the patients were admitted to the research unit to be studied over 24 hours. After a clinical assessment the dose of lisinopril was given under supervision with all concomitant medication. Blood sampling and measurements of heart rate and blood pressure were made at regular intervals throughout the 24 hours (fig 1). All urine passed during the study period was collected for analysis of creatinine, electrolytes, and ANP concentration. Urine collections from three patients were incomplete and all urine results from these patients were excluded from the analysis.

After this study period, patients took $10 \mathrm{mg}$ lisinopril once a day in addition to all usual medication for two weeks, after which they received another two weeks of treatment with either lisinopril $5 \mathrm{mg}$ once a day or $20 \mathrm{mg}$ once a day according to the randomisation plan. On

Figure 1 (A) Study plan showing daily dose of lisinopril and timing of study days. (B) Schedule of study days showing timing of supervised lisinopril medication; blood sampling for aldosterone angiotensin converting enzyme activity (ACE), endothelin, atrial natriuretic peptide (ANP), and $B$-type natriuretic peptide (BNP); and measurement of heart rate (HR) and blood pressure (BP).
A

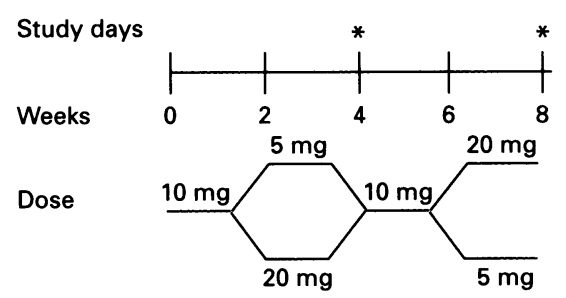

B

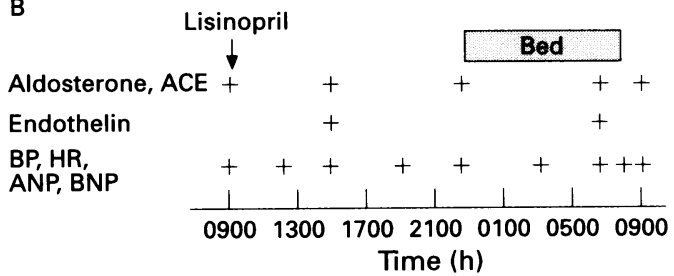

the last day of this second treatment period the patients were again studied over 24 hours as described above. The order of administration of low dose and high dose lisinopril was governed by balanced randomisation. Patient compliance was assessed by a tablet count.

Blood pressure measurements and all blood samples were taken after 30 minutes supine bed rest. Throughout the rest of the study period the patients were free to walk around; mealtimes and bedtimes were standardised as shown in figure 1 . Blood pressure was measured with a semi-automated sphygmomanometer (Dinamap) placed around the left arm. All of the measurements and laboratory analyses were performed by individuals who were blinded to the treatment.

\section{NATRIURETIC PEPTIDE ASSAYS}

Venous blood was taken into chilled tubes containing EDTA and aprotinin (Trasylol, Bayer, 4000 kallikrein inactivation units per tube). Plasma was separated immediately and stored at $-70^{\circ} \mathrm{C}$ until the measurement of ANP-like immunoreactivity (ANP-li) and BNP-li. Each peptide was measured in all of the samples from a patient in a single assay run. Plasma was applied to C8 solid phase extraction columns which had been pretreated with $4 \mathrm{ml}$ methanol, $4 \mathrm{ml}$ distilled water, and $4 \mathrm{ml} 1 \%$ trifluoroacetic acid. The columns were washed with $9 \mathrm{ml}$ of $1 \%$ trifluoroacetic acid and samples were eluted with $4 \mathrm{ml}$ of 95\% methanol and $1 \%$ trifluoroacetic acid. Samples were dried and the radioimmunoassay was performed with commercial kits supplied by Peninsula: ANP 1-28 (human, canine) and BNP 32 (human). Recovery of added peptides was $88 \%$ for ANP and $86 \%$ for BNP. The coefficients of variability for each assay were: ANP inter-assay $=11 \cdot 8 \%$, intraassay $=12.6 \% ; \quad$ BNP inter-assay $=14.8 \%$, intra-assay $=9 \cdot 9 \%$. Urinary ANP was measured, without any prior extraction procedure, by radioimmunoassay.

\section{ENDOTHELIN ASSAYS}

Samples were taken and stored as described above for the natriuretic peptide assays. Plasma immunoreactive endothelin was measured by radioimmunoassay as described previously. ${ }^{10}$ The recovery of added endothelin was $84 \%$. Intra and inter assay coefficients of variability were $2.4 \%$ and 4.25 respectively. The sensitivity of this assay is $2 \mathrm{pg} / \mathrm{ml}$ endothelin. Cross reactivity of the assay with endothelin-1, endothelin-2, endothelin-3, and proendothelin is $100,52,96$, and $7 \%$ respectively

\section{ALDOSTERONE ASSAYS}

Blood samples for measurement of plasma aldosterone activity were taken into lithiumheparin tubes; plasma was separated immediately and stored at $-20^{\circ} \mathrm{C}$ until analysis. Radioimmunoassay was performed using a standard commercial kit (Sorin, Italy). The intra-assay coefficient of variability was $7 \cdot 8 \%$ and the inter-assay coefficient of variability was $9 \cdot 6 \%$. 
Table 1 Patient characteristics

\begin{tabular}{lc}
\hline Variable & - \\
\hline Male & $16(84) \%$ \\
Age (mean (SD)) & $60 \cdot 3(7 \cdot 6) \mathrm{y}$ \\
LVEF (mean (SD)) & $31 \cdot 2(16 \cdot 0) \%$ \\
NYHA class II & $12(63) \%$ \\
$\begin{array}{l}\text { NYHA class III } \\
\text { Duration of ACE inhibitor } \\
\text { treatment (mean (SD)) }\end{array}$ & $7(37) \%$ \\
$\begin{array}{l}\text { Diuretic dose - equivalent dose } \\
\text { of frusemide (mean (SD)) }\end{array}$ & $17 \cdot 1(14 \cdot 8)$ months \\
\hline $\begin{array}{l}\text { LVEF, left ventricular ejection fraction; NYHA, New York } \\
\text { Heart Association. }\end{array}$ & $67 \cdot 4(45 \cdot 6)$ mg \\
\hline
\end{tabular}

Figure 2 (A) Systolic and $(B)$ diastolic blood pressure over 24 hours in patients taking $5 \mathrm{mg}$ and $20 \mathrm{mg}$ of lisinopril. Results are expressed as mean (SEM).
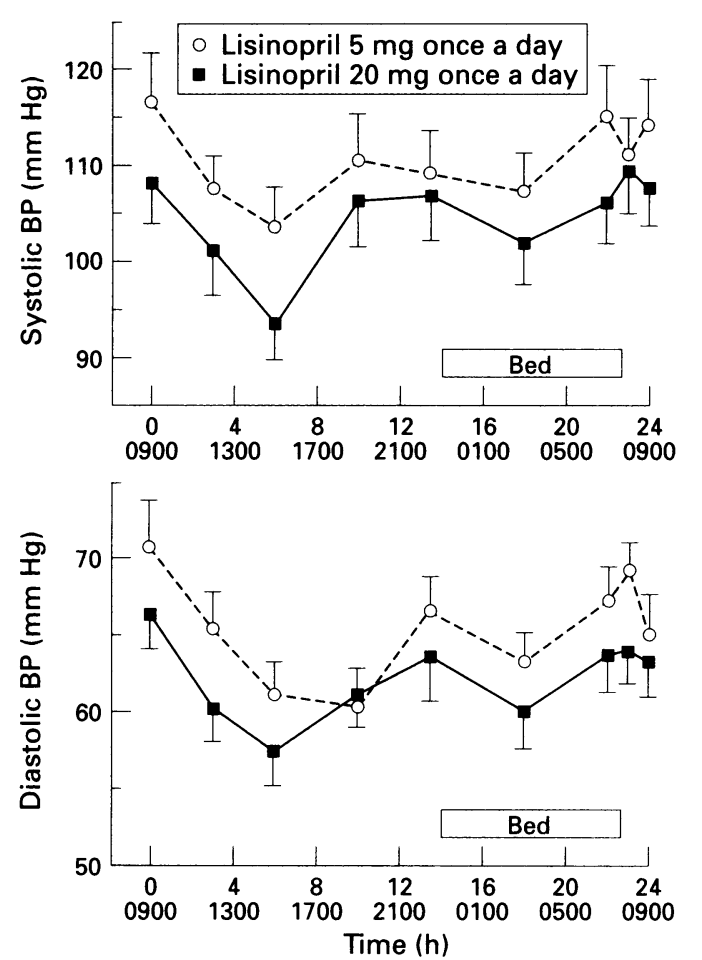

Figure 3 Creatinine clearance in patients taking $5 \mathrm{mg}$ and $20 \mathrm{mg}$ of lisinopril. Values for individual patients are shown.

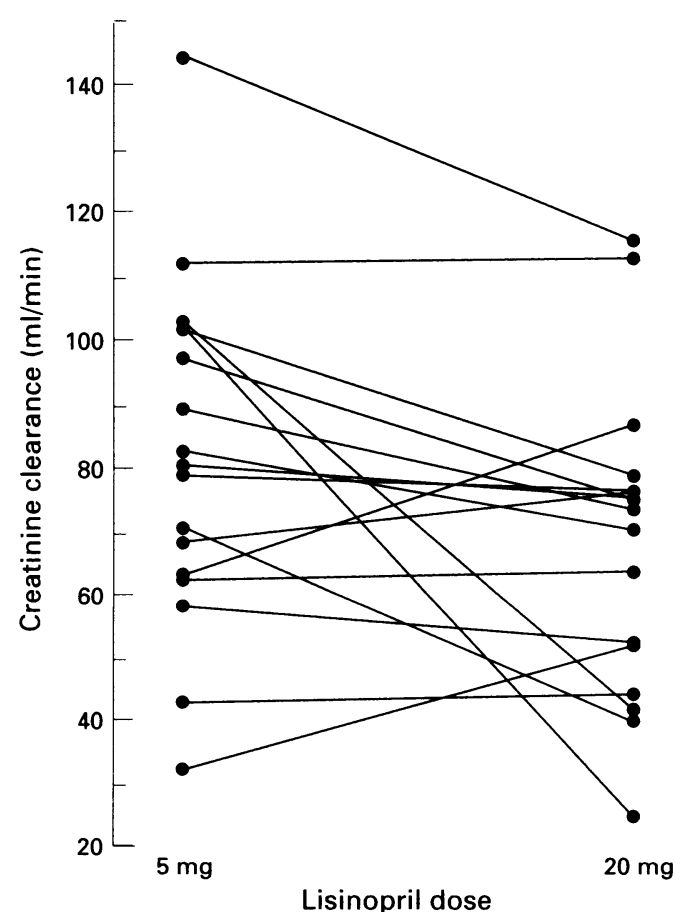

PLASMA ACE ACTIVITY

Blood samples for measurement of plasma ACE activity were taken into lithium-heparin tubes; plasma was separated immediately and stored at $-20^{\circ} \mathrm{C}$ until analysis. Plasma ACE activity was determined by the spectrophotometric kinetic rate method, using the synthetic substrate N-3-(2-furyl) acryloyl-L-phenylalanylglycylglycine. ${ }^{11}$

\section{ACE GENOTYPE}

Before the study, blood samples were taken for detection of the insertion/deletion polymorphism of the gene for angiotensin-converting enzyme. This was determined from leucocyte DNA using the polymerase chain reaction. ${ }^{12}$

\section{STATISTICAL ANALYSIS}

For plasma concentrations of ANP, BNP, and aldosterone the results were summarised as mean at peak effect (mean of 6 and 13.5 hour values for aldosterone; mean of 6 and 10 hour values for ANP and $B N P$ ), mean at trough effect (mean of 22 and 24 hour values for aldosterone; mean of 22,23 , and 24 hour values for ANP and BNP), and area under the curve for the values over 24 hours (calculated according to the trapezoidal method and divided by the time period). For blood pressure and heart rate, values were expressed as area under the curve. These summary measures were compared between treatments using the analysis of variance methods (ANOVA) of Grizzle, ${ }^{13}$ which incorporate effects due to period and carry-over of the previous treatment. The analysis for these variables is presented using differences between adjusted means for the two treatments (adjusted for treatment period effects). All other variables, which had one or two values for each dose were compared using two-tailed paired $t$-tests. The assessment of carry-over effects is a between-patient evaluation and the test for carry-over was therefore performed at the $10 \%$ level of significance. All other tests were performed at the $5 \%$ level of significance.

\section{Results}

Baseline characteristics of the patients are shown in table 1 . The compliance rate was $>85 \%$ for each patient in all parts of the study. There were no significant differences in symptomatic status, clinical findings, or patient weight between the two doses of lisinopril. There was no evidence of a significant period or carry-over effect for any of the variables measured.

\section{BLOOD PRESSURE AND HEART RATE}

Blood pressure values on each dose of lisinopril are shown in figure 2. The mean area under the curve for systolic blood pressure was lower during the high-dose phase than during the low-dose phase, although this effect was of borderline statistical significance $(P=0.05)$. The difference between the adjusted treatment means ( $5 \mathrm{mg}$ dose minus $20 \mathrm{mg}$ dose) was $5 \cdot 7$ $(95 \% \mathrm{CI} 0.0$ to 11.5$) \mathrm{mm} \mathrm{Hg}$. The mean area under the curve for diastolic blood pressure 
Table 2 Plasma electrolytes 24 hour urinary electrolytes and atrial natriuretic peptide $(A N P)$ excretion and creatinine clearance in patients taking $5 \mathrm{mg}$ and $20 \mathrm{mg}$ of lisinopril (mean $(S D)$ )

\begin{tabular}{|c|c|c|}
\hline \multirow[b]{2}{*}{ Variable } & \multicolumn{2}{|l|}{ Lisinopril dose } \\
\hline & $5 m g$ & $20 \mathrm{mg}$ \\
\hline $\begin{array}{l}\text { Plasma }(\mathrm{Na})(\mathrm{mmol} / \mathrm{l}) \\
\text { Plasma }(\mathrm{K})(\mathrm{mmol} / \mathrm{l}) \\
\text { Plasma }(\mathrm{creatinine})(\mathrm{mmol} / \mathrm{l}) \\
24 \text { hour urine } \mathrm{Na} \text { excretion }(\mathrm{mmol}) \\
24 \text { hour urine } \mathrm{K} \text { excretion }(\mathrm{mmol}) \\
\text { Creatinine clearance }(\mathrm{ml} / \mathrm{min}) \\
24 \text { hour urinary ANP excretion (pmol) }\end{array}$ & $\begin{array}{l}137 \cdot 3(2 \cdot 45) \\
4 \cdot 11(0 \cdot 47) \\
111 \cdot 7(22 \cdot 7) \\
207 \cdot 6(82 \cdot 8) \\
88 \cdot 4(27 \cdot 8) \\
82 \cdot 2(27 \cdot 1) \\
13 \cdot 6(4 \cdot 3)\end{array}$ & $\begin{array}{l}138 \cdot 1(2 \cdot 43) \\
4 \cdot 18(0 \cdot 38) \\
113 \cdot 4(25 \cdot 7) \\
212 \cdot 0(83 \cdot 6) \\
80 \cdot 2(22 \cdot 1) \\
68 \cdot 7(24 \cdot 4)^{\star} \\
12 \cdot 2(4 \cdot 5) \dagger\end{array}$ \\
\hline
\end{tabular}

${ }^{\star} \mathrm{P}<0.05$ for $5 \mathrm{mg} v 20 \mathrm{mg} ; \mathrm{P}=0.02$ for $5 \mathrm{mg} v 20 \mathrm{mg}$.

Figure 4 Plasma aldosterone concentrations over 24 hours in patients taking $5 \mathrm{mg}$ and $20 \mathrm{mg}$ lisinopril. Results are expressed as mean (SEM)

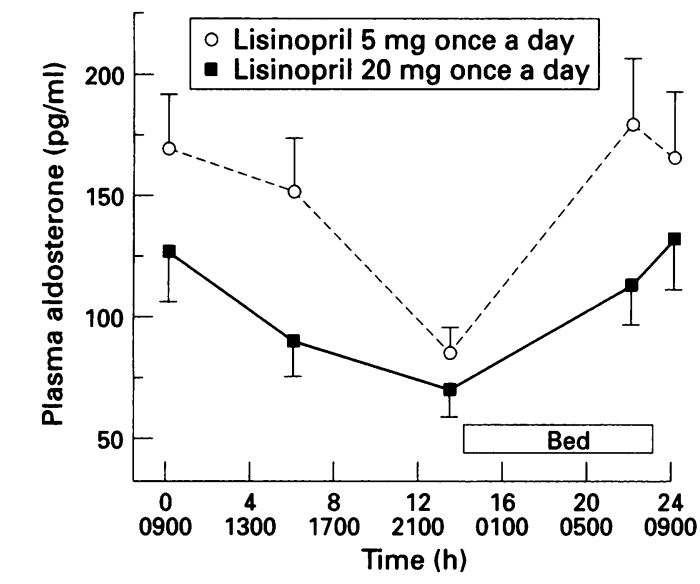

Table 3 Plasma ACE activity in groups divided according to $A C E$ genotype (mean (SD))

\begin{tabular}{llc}
\hline & \multicolumn{2}{l}{ Lisinopril dose } \\
\cline { 2 - 3 }$A C E$ genotype & $5 \mathrm{mg}$ & $20 \mathrm{mg}$ \\
\hline DD $(\mathrm{n}=7)$ & $14 \cdot 38(2 \cdot 79)$ & $10 \cdot 27(3 \cdot 76)$ \\
ID $(\mathrm{n}=7)$ & $11 \cdot 49(8 \cdot 87)$ & $8 \cdot 87(2 \cdot 62)$ \\
II $(\mathrm{n}=5)$ & $9 \cdot 80(4 \cdot 67)$ & $7 \cdot 95(2 \cdot 62)$ \\
Total $(\mathrm{n}=19)$ & $12 \cdot 11(3 \cdot 83)$ & $9 \cdot 14(3 \cdot 07)^{\star}$
\end{tabular}

*Area under curve over 24 hours expressed as standard international units. $\mathrm{P}<0.01$ for $5 \mathrm{mg} v 20 \mathrm{mg}$.

$\mathrm{ACE}$, angiotensin converting enzyme.

Figure 5 Mean plasma concentrations over 24 hours of $(A)$ atrial natriuretic peptide and $(B)$ $B$-type natriuretic peptide in patients taking $5 \mathrm{mg}$ and $20 \mathrm{mg}$ of lisinopril.
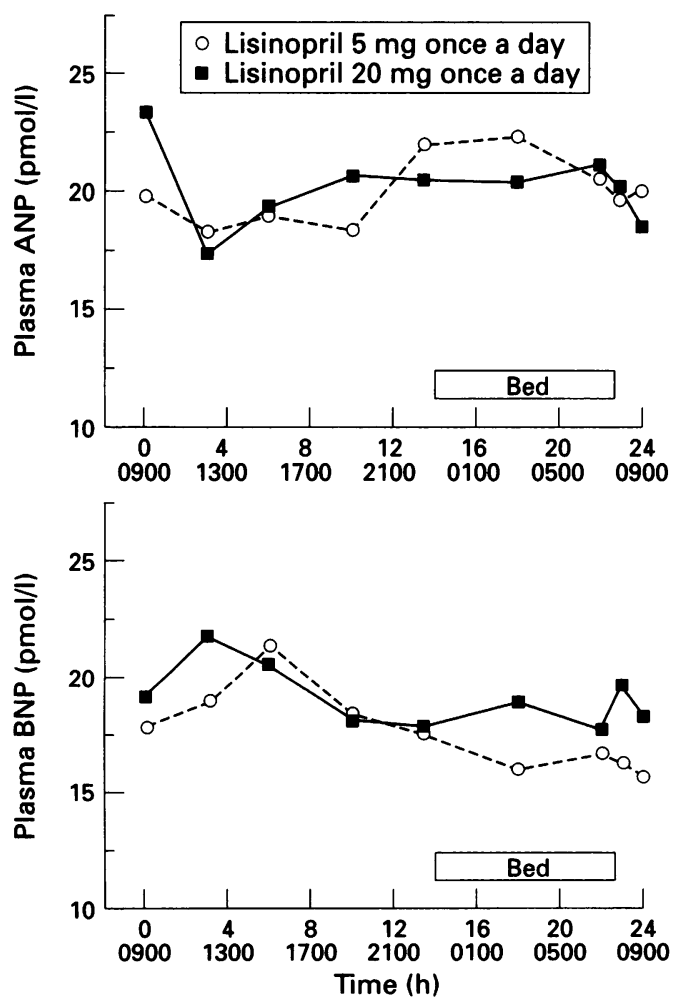

was significantly lower during the high-dose phase than during the low-dose phase ( $P=$ $0 \cdot 04)$. There was no significant difference in heart rate between doses.

\section{PLASMA /URINARY ELECTROLYTES AND} CREATININE CLEARANCE

Creatinine clearance was significantly lower on the $20 \mathrm{mg}$ dose than on the $5 \mathrm{mg}$ dose (fig 3). There were no significant differences between plasma and urinary electrolyte concentrations between doses (table 2).

\section{ALDOSTERONE CONCENTRATIONS}

Plasma aldosterone concentrations were significantly lower on the $20 \mathrm{mg}$ dose than on the $5 \mathrm{mg}$ dose (fig 4). Mean at peak effect $90.7 \mathrm{v}$ $152.0 \mathrm{pg} / \mathrm{ml}, \mathrm{P}<0.001$; mean at trough effect $124.7 v 174.4 \mathrm{pg} / \mathrm{ml}, \mathrm{P}<0.01$. For the area under the curve, the difference between the treatment means $(5 \mathrm{mg}$ dose minus $20 \mathrm{mg}$ dose) was $44.0(95 \%$ CI 24.0 to 63.9$) \mathrm{pg} / \mathrm{ml}$ $(\mathrm{P}<0.001)$.

NATRIURETIC PEPTIDE CONCENTRATIONS

Plasma concentrations of natriuretic peptides are shown in figure 5 . There were no significant differences in the area under the curve or the concentrations at peak or trough drug effect for either ANP or BNP on the two doses. Urinary excretion of ANP over 24 hours was significantly lower on $20 \mathrm{mg}$ lisinopril than on the $5 \mathrm{mg}$ dose.

\section{ENDOTHELIN CONCENTRATIONS}

Plasma concentrations of endothelin at six hours (peak drug effect) were $4.74 v 3.27$ $\mathrm{pmol} / \mathrm{l}$ on $5 \mathrm{mg}$ lisinopril and $5.01 v 2.98$ on $20 \mathrm{mg}$ lisinopril (mean (SD), $P=N S$ ). At 22 hours (trough drug effect) concentrations were $6.04 v 3.58 \mathrm{pmol} / 1$ on $5 \mathrm{mg}$ lisinopril and 4.70 v $2.72 \mathrm{pmol} / \mathrm{l}$ on $20 \mathrm{mg}$ lisinopril $(\mathrm{P}=0.03)$.

\section{PLASMA ACE ACTIVITY}

Plasma ACE activity was significantly lower on high-dose than on low-dose lisinopril (table 3). There was a non-significant trend towards lower ACE activity on both doses of lisinopril in patients with the II genotype than in patients with either the ID or DD genotype.

\section{Discussion}

The results of this study demonstrate significant dose-related effects of lisinopril within the usual therapeutic range in patients with chronic heart failure. It is important to note that because all of the patients were established on ACE inhibitor treatment for at least one month before the study, they had all received a minimum of six weeks treatment before the first study day. In fact, as figure 1 shows, most patients had been treated with ACE inhibitors for considerably longer periods; the results therefore represent the response to chronic ACE inhibition. As expected, the higher dose of lisinopril caused a greater degree of inhibition of ACE than the lower dose. There was no evidence of a large difference in the dose-response relation for any 
of the variables measured between the three groups of insertion/deletion polymorphisms of the ACE gene, but this study was not designed to detect such a difference and the numbers of patients with each of the three genotypes were small.

The superior suppression of aldosterone produced by the higher dose of lisinopril is striking. The early morning rise in plasma aldosterone which was seen on both doses of lisinopril occurred before the patients got out of bed. It is uncertain whether this was due primarily to the diurnal pattern of adrenocorticotrophic hormone (ACTH) release or due to reduced drug effect at this time; the large difference in early morning aldosterone concentrations between the two doses suggests an important drug effect, but even on the higher dose the suppression of aldosterone was not sustained over the 24 hour period. The importance of aldosterone in heart failure is that it has been shown experimentally to cause a wide range of potentially detrimental effects. These include increased potassium and magnesium excretion (which may promote arrhythmias), ${ }^{14}$ impairment of baroreceptor function, ${ }^{15}$ and stimulation of myocardial fibrosis. ${ }^{16}$ We found that during long-term treatment with an ACE inhibitor suppression of aldosterone can be improved by increasing the dose of the ACE inhibitor but this suppression was incomplete, especially in the early morning. Further suppression of plasma aldosterone may be achieved by using even higher doses of an ACE inhibitor, nocturnal dosing with an ACE inhibitor, the addition of a receptor antagonist, or a combination of these approaches.

The role of the endothelins in the pathophysiology of cardiovascular disease is not clearly established. It is known that the plasma concentrations of these peptides are increased in heart failure ${ }^{17}$ and the concomitant increase in plasma concentrations of big endothelin- 1 is consistent with increased production of endothelins in heart failure. ${ }^{18}$ It has recently been reported that blockade of endothelin receptors causes vasodilatation in patients with heart failure, ${ }^{19}$ which suggests that endothelin contributes to the increase in vascular tone associated with this condition. Previously there have been conflicting reports of the effects of short-term ACE inhibition on plasma endothelin in experimental and clinical heart failure ${ }^{2021}$; the data from the current study provide the first evidence that endothelin concentrations can be suppressed more by high dose than by low strengthened by our observation that the higher dose of lisinopril reduced endothelin concentrations despite a fall in creatinine clearance, suggesting that reduced secretion of endothelins, rather than increased renal clearance, was reponsible for the effect. ACE inhibitors may reduce the secretion of endothelin by reducing the concentration of angiotensin II, a potent stimulant for endothelin release, ${ }^{22}$ or by increasing bradykinin activity, resulting in increased production of nitric oxide, an inhibitor of endothelin release. ${ }^{23}$ On the basis of current knowledge it is uncertain whether the observed difference in endothelin concentrations is of clinical relevance, but it suggests an intriguing alternative mechanism for some of the beneficial effects of ACE inhibitors.

The observed differences in blood pressure between the two doses of lisinopril are small overall, but six hours after dosing (that is, peak drug effect) the mean systolic blood pressure was about $10 \mathrm{~mm} \mathrm{Hg}$ lower and the mean diastolic blood pressure was about $4 \mathrm{~mm} \mathrm{Hg}$ lower on high dose than on low dose lisinopril (fig 2). Though most patients had very little change in creatinine clearance between doses, in some patients it dropped considerably on the higher dose. This was not associated with a rise in serum creatinine during the two weeks of the study, but it is possible that such alterations in renal function might be detrimental in the long term.

The similar plasma concentrations of atrial and B-type natriuretic peptide on each dose are surprising in view of the described differences in blood pressure. It seems likely that the reduction in afterload produced by the higher dose would result in a reduced secretion of these peptides from the myocardium, a process that is thought to depend mainly on cardiac stretch. ${ }^{24}$ Previous studies have reported a reduction in natriuretic peptide concentrations during acute ACE inhibition in heart failure ${ }^{7}$ but other investigators showed that the relation between plasma ANP concentrations and pulmonary capillary wedge pressure is weakened during ACE inhibition, ${ }^{25}$ a phenomenon which has not been fully explained. It is likely that in the present study any favourable cardiac effect of high dose lisinopril is offset by reduced renal clearance of ANP and BNP, due to reduced renal blood flow. This explanation is supported by the lower urinary concentrations of ANP on high dose than on low dose lisinopril.

In conclusion, suppression of plasma aldosterone and endothelin concentrations was greater on the $20 \mathrm{mg}$ dose of lisinopril than on the $5 \mathrm{mg}$ dose, but the observed falls in creatinine clearance associated with the higher dose may outweigh these beneficial effects in clinical practice. The issue of the optimal dose of ACE inhibitor should be settled by the results of the ATLAS (Assessment of Treatment with Lisinopril and Survival) trial which will ultimately provide data on clinical endpoints. In the meantime it is essential that renal function is monitored as the dose of ACE inhibitor is titrated upwards in patients with heart failure.

NCD was supported by a grant from the British Heart Foundation. This study was sponsored by Zeneca Pharmaceuticals. We thank Mark EC Dockrell for expert technical assistance.

1 CONSENSUS Trial Study Group. Effects of enalapril on mortality in severe congestive heart failure: results of the Cooperative New Scandanavian Enalapril Survival Study. N Engl F Med 1987;316:1429-35.

2 Vasodilator-Heart Failure Veterans Affairs Cooperative Study Group. A comparison of enalapril with hydraazine-isosorbide dinitrate in the treatment of chronic congestive heart failure. $N$ Engl f Med 1991;325:

3 The SOLVD investigators. Effect of enalapril on survival in patients with reduced left ventricular ejection fractions 
and congestive heart failure. $N$ Engl $f$ Med 1991;325: 293-302.

4 Cleland JGF, Poole-Wilson PA. ACE inhibitors for heart failure: a question of dose. Br Heart $\mathcal{F}$ 1994;72(suppl 3): 106-10.

5 Benjamin N, Cockcroft JR, Collier JG, Dollery CD, Ritter $\mathrm{JM}$, Webb DJ. Local inhibition of converting enzyme and vascular responses to angiotensin and bradykinin in the human forearm. F Physiol (Lond) 1989;412:543-55.

6 Emori T, Hirata Y, Schichiri M, Marumo F. Secretory mechanism of immunoreactive endothelin in cultured bovine endothelial cells. Biochem Biophys Res Commun 1989;160:93-100.

7 Yoshimura M, Yasue H, Tanaka H, Kikuta K, Sumida H, Kato $\mathrm{H}$, et al. Responses of plasma concentrations of $\mathrm{A}$ type natriuretic peptide and $\mathrm{B}$ type natriuretic peptide to alacepril, an angiotensin-converting enzyme inhibitor, in alacepril, an angiotensin-converting enzyme inhibitor, in
patients with congestive heart failure. $B r$ Heart $\mathcal{F} 1994$; patients with

8 Hall C, Rouleau JL, Moyè L, de Champlain J, Bichet D, Klein $\mathrm{M}$, et al. $\mathrm{N}$-terminal proatrial natriuretic factor: an Klein $\mathrm{M}$, et al. N-terminal proatrial natriuretic factor: an
independent predictor of long-term prognosis after independent predictor of long-term prognosis
myocardial infarction. Circulation 1994;89:1934-42

9 Tsutamoto T, Maeda Y, Wada A, Adachi T, Nakamura Y, Kinoshita M. Plasma brain natriuretic peptide concentraion as a prognostic predictor in patients with chronic congestive heart failure (abstract). Circulation 1993;88 (suppl 4 Pt2):I-26

10 Haynes WG, Hand MF, Johnstone HA, Padfield PL, Webb DJ. Direct and sympathetically mediated venoconstriction in essential hypertension. Enhanced responses to endothelin-1. F Clin Invest 1994;94:1359-64.

11 Holmquist B, Bünning P, Riordan JF. A continuous spectrophotometric assay for angiotensin converting enzyme. Anal Biochem 1979;95:540-8.

12 Rigat B, Hubert C, Corvol P, Soubrier F. PCR detection of the insertion/deletion polymorphism of the human angiotensin converting enzyme gene (dipeptidyl carboxypeptidase). Nucleic Acids Res 1992;20:1433.

13 Grizzle JE. The two-period change-over design and its use in clinical trials. Biometrics 1965;21:467-80.

14 Leier CV, Dei Cas L, Metra M. Clinical relevance and management of the major electrolyte abnormalities in congestive heart failure: hyponatraemia, hypokalaemia and hypomagnesaemia. Am Heart $\mathcal{f}$ 1994;128: 564-74.
15 Wang W. Chronic administration of aldosterone depresses baroreceptor reflex function in the dog. Hypertension 1994;24:571-5.

16 Weber KT, Brilla CG. Pathological hypertrophy and the cardiac interstitium: fibrosis and the renin-angiotensinaldosterone system. Circulation 1990;83:1840-65.

17 McMurray JJ, Ray SG, Abdullal I, Dargie HJ, Morton JJ. Plasma endothelin in chronic heart failure. Circulation 1992;85:1374-9.

18 Pacher R, Bergler-Klein J, Globits S, Teufelsbauer $H$, Schuller M, Krauter A, et al. Plasma big endothelin-1 concentrations in congestive heart failure patients with or without systemic hypertension. Am $f$ Cardiol 1993;71: 1293-9.

19 Kiowski W, Bertel O, Sütsch G, Hunziker P, Müller P, Schmitt R, et al. Vasodilator effects of the endothelin-1 receptor antagonist bosentan in patients with severe receptor antagonist bosentan in patients with severe
chronic heart failure (abstract). $\mathcal{I}$ Am Coll Cardiol 1995; 25(suppl):I-779.

20 Clavell AL, Mattingly MM, Nir A, Aarhus LL, Heublein DM, Burnett JC. Angiotensin converting enzyme inhibiDM, Burnett JC. Angiotensin converting enzyme inhibition modulates circulating and tissue endothelin activity in experimental heart

21 Townend J, Doran J, Jones S, Davies M. Effect of angiotensin converting enzyme inhibition on plasma endothelin in congestive heart failure. Int $\mathcal{F}$ Cardiol 1994; 43:299-304.

22 Yanagisawa $M$, Kurihara $H$, Kimura S, Tomobe $Y$, Kobayashi M, Mitsui Y, et al. A novel potent vasoconstrictor peptide produced by vascular endothelial cells. Nature 1988;332:411-5.

23 Boulanger C, Lüscher TF. Release of endothelin from the porcine aorta: inhibition by endothelium-derived nitric oxide. 7 Clin Invest 1990;85:587-90.

24 Yasue H, Yoshimura M, Sumida H, Kikuta K, Kugiyama $\mathrm{K}$, Jougasaki $\mathrm{M}$, et al. Localization and mechanism of secretion of B-type natriuretic peptide in comparison with those of A-type natriuretic peptide in normal subjects and patients with heart failure. Circulation 1994; 90:195-203.

25 Berglund $H$, Nyquist $O$, Beerman B, Jensen-Urstad $M$, Theodorsson $\mathrm{E}$. Influence of angiotensin converting enzyme inhibition on relation of atrial natriuretic peptide
to atrial pressure in heart failure. $B r$ Heart $\mathcal{f} 1994 ; 72$ : 521-7. 